\title{
FORMAL MENTORING: MENTEE AND MENTOR EXPECTATIONS AND PERCEIVED CHALLENGES
}

\author{
SONIA D C PINHO \\ MELINDE COETZEE \\ DRIES SCHREUDER \\ Department Industrial \& Organisational Psychology \\ College of Economic and Management Sciences \\ University of South Africa
}

\begin{abstract}
The purpose of this study was to investigate the expectations and perceived challenges of mentees and mentors regarding a formal mentoring programme within the South African work context. The convenience sampling method was used to identify respondents $(\mathrm{N}=12)$. Qualitative methods were used to collect and analyse data on the respondents' views on the formal mentoring programme. The results suggest that male and female mentees differ in terms of their expectations and the challenges they perceive in the formal mentoring relationship. The expectations of mentees also appear to be different from those of mentors regarding the formal relationship.
\end{abstract}

\section{OPSOMMING}

Die doel met hierdie studie was om die verwagtinge en beskouing van mentees en mentees omtrent 'n formele mentorprogram binne die Suid-Afrikaanse werkskonteks te ondersoek. Gerieflikheidsteekproefneming is aangewend om respondente $(\mathrm{N}=12)$ te identifiseer. Kwalitatiewe metodes is benut om die respondente se standpunt aangaande die mentorverhouding te versamel en te ontleed. Die resultate dui 'n verskil aan in die verwagtinge en sieninge van manlike en vroulike mentees. Die verwagtinge van mentees blyk ook te verskil van mentors se verwagtinge rakende die formele verhouding.

The changing organisational context of careers has received an enormous amount of attention (Feldman, 2002). Careers have become repositories of information, knowledge, skills, expertise and relationship networks acquired through an evolving sequence of work experiences over time (Baruch, 2004). National legislation such as the Employment Equity Act and the Skills Development Act has given rise to a situation where people now have greater choice, greater flexibility, more opportunities and a better quality of life, but also experience less job security, stability and certainty during their careers due to a constantly changing and uncertain workplace (Coetzee \& Stone, 2004). In a world of greater volatility, uncertainty, change, and ambiguity, the need for continuous learning has never been greater. As such, developmental relationships, as for example mentoring, are increasingly becoming a source of meaningful feedback, psychological safety, stability and continuous professional growth (Hall \& Kahn, 2002). Against this background, formal mentoring programmes are being seen as a way to establish learning relationships that enable the continuing development of employees. In the South African context formal mentoring programmes have also become a tool for promoting the growth and development of junior employees and people from historically disadvantaged groups (Young \& Perrewe, 2004).

Research findings indicate that mentoring may increase job satisfaction, career attainment and organisational commitment (Scandura \& Williams, 2002). Mentoring is also associated with lower intent to leave the job and reduced role stress (Baugh, Lankau \& Scandura, 1996). Organisations often encourage mentoring through formal programmes, since mentoring may play a role in increasing performance and improving work attitudes (Murray, 1991; Scandura \& Williams, 2002). Many formal programmes, however, have encountered problems as members report discomfort and mentees appear to receive fewer benefits than mentees in informal mentoring relationships (Scandura \& Williams, 2002). Unrealistic expectations may be held for mentors, while problems with matching individuals, and in identifying potential mentors may also be encountered (Klasen \& Clutterbuck, 2002; Scandura, 1998).

Requests for copies should be addressed to: M Coetzee, coetzm1@unisa.ac.za
Mentoring has been around for many generations and, although the definition and type of mentoring may have been adapted during various eras, the essence has remained the same (Klasen \& Clutterbuck, 2002; Gibb, 1994). The Aristocratic era was characterised by feudal fathers providing knowledge and guidance to their eldest sons (Clawson, 1996). However, as population growth began to soar in the Industrial era, mentoring provided a way in which senior people could connect with the next generation as more than boss or supervisor. Thus mentoring provided a way for the new generation to receive more personalised guidance in their progress upwards (Wickman \& Sjodin, 1997). The contemporary organisational context is characterised by flatter, networked structures utilising a diverse yet empowered workforce (Clawson, 1996). Mentoring in the contemporary context provides the opportunity for people to connect in a meaningful way with older people, to learn about the management of the business and about life, and to balance the two (Higgins, 2000).

Mentoring is a dyadic relationship in which an older, more experienced member of the organisation fosters the growth and development of a junior employee to a point where he or she becomes a competent professional (Scandura \& Williams, 2002). Mentoring is also viewed as a dynamic, developmental relationship between two individuals, based on trust and reciprocity, leading toward the enhancement of junior members' psychological growth and career advancement and toward achieving mutual benefits for the mentor, mentee and organisation (Appelbaum, Ritchie \& Shapiro, 1994; Johnson, Geroy \& Griego, 1999; Kochan, 2002; Seibert, 1999). A developmental relationship is characterised by Douglas and McCauley (1999) as a relationship that motivates individuals to learn and grow through exposure to new opportunities and the provision of needed support.

Research suggests that mentoring involves vocational or career development, psychosocial support, and role modelling (Dreher \& Ash, 1990; Scandura, 1992; Scandura \& Williams, 2002). Career development functions comprise sponsorship, exposure to advantageous projects, protection and coaching (Young \& Perrewe, 2004) whereas psychosocial functions are more oriented toward a support function that aids in the formation of 
one's self-concept (Mullen, 1998). Psychosocial functions include acceptance, role modelling, confirmation and friendship (Higgins, 2000; Seibert, 1999).

\section{Formal mentoring}

The mentoring relationship can be either formal or informal (Appelbaum et al, 1994; Chao, Walz \& Gardner, 1992; Johnson et al, 1999; Klasen \& Clutterbuck, 2002). Cunningham (1993) describes formal mentoring programmes as those in which the organisation assigns or matches mentors and mentees, provides them with top management support, an extensive orientation programme, clearly stated responsibilities for each party, established duration and contact, and emphasised realistic expectations regarding the relationship. Informal mentoring is characterised by a more relaxed environment in which the mentoring relationship develops spontaneously (Ragins \& Cotton, 1999; Wickman \& Sjodin, 1997). It is viewed as a relationship which, according to Young and Perrewe (2004), is continually negotiated between two partners. Ragins and Cotton (1991) noted that women might be more likely to seek formal mentoring programmes as substitutes for informal mentorships since they face greater barriers than men in their efforts to establish informal relationships with mentors.

While research on both formal and informally initiated mentoring relationships has emphasised the associated benefits, there is increasing recognition of the potential that formal mentoring relationships have for becoming dysfunctional relationships (Scandura, 1998; Scandura \& Williams, 2002). Eby, McManus, Simon and Russell (1998) describe dysfunctional mentoring relationships in which mentees reported having dissimilar attitudes, values, and beliefs in assigned mentoring relationships. Formal mentors are often selected by mentees based on their competence and there is less likely to be the mutual respect, friendship, and mutual attraction that might be found in an informal mentoring relationship (Ragins \& Cotton, 1999). Mismatches do occur in formalised mentoring and may result in relationships being characterised by discontent, anger, jealousy, resentment, sabotage, deception or harassment (Scandura \& Williams, 2002). In an informal mentoring relationship there may be greater levels of commitment to the relationship by both parties because of mutual interest. Informal relationships will also be more likely to involve the vocational, psychosocial, and role-modelling elements of mentoring (Scandura \& Williams, 2002). However, since the purpose of many formal mentoring programmes is to advance task-oriented and career-oriented goals for mentees, the time spent together tends to be less than in informal mentoring relationships with resultant reduced psychosocial support and role modelling (Gray, 1988; Scandura \& Williams, 2002).

On the negative side, the development of formal, facilitated mentoring programmes may involve considerable time, effort and cost on the part of the organisation (Seibert, 1999). Appelbaum et al (1994), which may also indicate why few formal mentoring programmes have succeeded in organisations due to the matching process, which is often perceived as a forced pairing. Further identified problems include unrealistically high expectations on the part of mentees, the excessive amount of time spent on the relationship, and the incompetence and lack of training of mentors (Rigsby, Siegel \& Spiceland, 1998). Despite the potential for dysfunctions in formal mentoring relationships, there is also evidence that the formal mentoring process can work effectively for mentees, mentors and organisations, particularly in cases where the matching process has been guided, formal mentoring has been offered in partnership with informal mentoring and mentors and mentees have been trained to engage in the mentoring relationship (Scandura \& Williams, 2002).
Reasons for the formation of mentoring relationships

Mentoring offers mentees a sense of career security and allows them to feel that their careers are more effectively and efficiently directed (Clutterbuck, 2001; Higgins, 2000; KoglerHill \& Bahniuk, 1998). This gives rise to increased career commitment (Appelbaum et al.1994). Mentoring provides learning benefits on the part of mentors (Hale, 2000) as well as a way for them to redirect their energies, gain respect and even fulfil generativity needs, which may in itself be rewarding (Scandura, Manuel, Werther \& Lankau, 1996). As the mentee learns from the mentor, the growth and learning potential inherent in the relationship decreases. On the other hand, the mentee's achievement potential increases and the relationship moves on to one of co-learning (Parsloe \& Wray, 2000; Scandura et al, 1996).

According to Mullen (1998), mentees tend to be attracted to mentors whom they perceive as interpersonally competent, and mentors are also drawn to mentees they perceive as being competent. Furthermore, mentors select mentees with characteristics similar to theirs and their perception that the mentee is a stereotype of an effective subordinate (Clutterbuck \& Ragins, 2002; Hale, 2000). However, Johnson, Geroy and Griego (1999) warn that when a mentee is selected on the basis of perceived similarity there is a tendency toward homogeneous reproduction, and mentors tend to mould an image of their own characteristics. If mentees are selected on the basis of a rich amount of differences, this could possibly result in a dysfunctional relationship due to a mutual inability to empathise. It was suggested by Hale (2000) that the selection of mentees be based on their talent, eagerness to learn and willingness to participate in the mentoring programme. The greater the hierarchical distance between mentor and mentee, the greater the communication gap and the less the interaction (Clutterbuck \& Lane, 2005; Mullen, 1998), hampering both mutual trust and obligation (Scandura et al, 1996).

\section{Challenges of mentoring}

Various factors influence the nature and quality of the mentoring relationship. Some of these factors are external to the mentoring association, such as the objectives of the formal mentoring programme and time issues. For example, the nature of mentoring relationships will be very different in an organisation that is downsizing as opposed to one that is expanding. In the former, the focus of the relationship should be on coping with the change, whilst in the latter case, the focus might be on developing employees for new roles. Time issues relate to potential limitations that may result from mentor or mentee work and life demands, costs or simply scheduling problems. Other factors are internal to the relationship, such as personality, gender, the personal style of the mentor and the needs of the mentee (Klasen \& Clutterbuck, 2002).

Negative mentor behaviour also occurs and is common when mentors overwork their mentees and take credit for their accomplishments, spend more time in impression management and self-promotion (Eby, McManus, Simon and Russell, 2000). Dealing with negative relationships is but one of the many challenges faced within the mentoring relationship. There is also the challenge of ensuring that formal mentors do not become overly dominant, causing the mentees to lose their sense of selfsufficiency (Rigsby et al, 1998). Caution needs to be taken in instances where mentees put the needs of their mentor ahead of their own as a career strategy (Scandura et al., 1996).

Mentoring relationships can, according to Scandura and Williams (2002), become dysfunctional in terms of overdependence, resentment, deception or harassment. The mentoring relationship may often be viewed as negative in terms of fairness because colleagues and peers will see it as a means of "getting ahead" (Scandura et al, 1996). This aspect is especially sensitive in cross-gender and cross-race relationships where mentoring programmes are seen as being remedial for females 
and blacks (Eby et al, 2000). According to Blake-Beard (2001), it is important that both mentors and mentees in cross-race and cross-gender relationships consider impeding factors such as the unrealistic expectations of mentees, lack of mutual attraction or mentoring opportunities, unskilled management and an unbalanced focus on the mentee by the mentor. There are also several external factors which may influence the mentoring relationships for females. These include the threat managers may feel that their management style is under scrutiny and the power they have to retract the availability of resources (Blake-Beard, 2001). Additional aggravating factors for females include the perception of sexual innuendos, rumours, overprotection and paternalism (Eby et al, 2000; Kochan, 2002).

Despite the potential for dysfunctions in formal mentoring relationships, the literature indicates that the process can work effectively for mentees and mentors (Klasen \& Clutterbuck, 2002; Scandura \& Williams, 2002). However, perspectives on mentee and mentor experiences of the challenges encountered in the formal mentoring relationship are under-researched in the South African organisational context. The purpose of this study was therefore to gain an understanding of mentors' and mentees' subjective views on the formal mentoring relationship. More specifically, the aim was to answer the following research questions:

- What are mentors' and mentees' expectations of the formal mentoring relationship?

- What are the key challenges of the formal mentoring relationship as perceived by mentors and mentees?

\section{RESEARCH DESIGN}

Research approach

A qualitative approach was decided upon, since this approach is specifically suitable when the research takes place in a natural setting. Qualitative research attempts to make sense of and interpret constructs and phenomena in terms of the meanings that people ascribe to them, thus seeking to give meaning to social experience (Denzin \& Lincoln, 1994). Merriam (2002) also recommends that a qualitative approach be used when the research objectives are exploratory and descriptive. Since the research questions pertain to understanding and describing a particular phenomenon about which very little is known, the qualitative approach appeared to be the most suitable for gaining insight into respondents' expectations of and their views on the challenges of the formal mentoring relationship in their work setting (Creswell, 1994).

This study was therefore conducted within a qualitative paradigm and the grounded theory method was used to develop an inductively derived theory (Strauss \& Corbin, 1990). This method enabled the researcher to study the phenomenon (the formal mentoring relationship) within its context and facilitated the systematic generation of theoretical principles from, and grounded in, the data regarding the respondents' expectations of and views on the challenges of the formal mentoring relationship.

\section{Respondents}

The study was conducted in a South African global pulp and paper manufacturer. Six (6) mentees and 6 mentors $(\mathrm{N}=12)$ formed a convenience sample (Huysamen, 1994) for the present study. Respondents from the sample of mentees constitute 3 white females, 1 coloured female, 1 African male and 1 Indian male. The respondents from the mentor sample constitute 5 white males and 1 white female. Table 1 provides an overview of the pairing relationship between the gender and race groups. Overall, this study focused on six relationships as indicated in Table 1 . These six relationships are in 3 cases cross-gender relationships (3 white female mentees and 3 white male mentors); in 1 case a cross-race relationship (1 Indian male mentee and 1 white male mentor) and in 2 cases cross-gender and cross-race relationships (1 coloured female mentee and 1 white male mentor; 1 African male mentee and 1 white female mentor). The selection of the respondents was based on their involvement in the formal mentoring programme of the company.

TABLE 1

\section{Pairing Relationship: Mentors and mentees}

\begin{tabular}{ll}
\hline Mentee & Mentor \\
\hline Coloured female & White male \\
White female & White male \\
White female & White male \\
White female & White male \\
African male & White female \\
Indian male & White male \\
TOTAL: 6 & TOTAL: 6 \\
\hline
\end{tabular}

\section{A brief background to the formal mentoring programme} The organisation has implemented a formal mentoring programme which is used as part of the learnership/internship programme, succession planning and management development, that is, it has been implemented as a compulsory requirement for the leadership academy. Mentoring is voluntary for mentors and the main aim is to provide growth and development. In addition, the organisation plans to use mentoring as a mechanism to assist the company to meet its employment equity objectives. The focus is on short-term relationships, which are purely developmental. The selection of a mentor can be either assisted or non-assisted, in which case the mentee approaches the Human Resource Development (HRD) practitioner who assists in identifying a suitable match in a mentor. There is no standard guideline which the HRD practitioner follows to match individuals. A yearly survey is sent to all mentoring pairs as a means of evaluating the effectiveness of the programme and, to date, feedback has been positive.

Once individuals have been matched, they undergo a formal training programme to learn about the mentoring programme and the challenges and benefits characteristic of a mentoring relationship. Structured guidelines are provided to the mentoring pairs. It has been identified that those pairs which have used the structured guides to assist in their mentoring relationship claim to have learned more compared to those who follow the more unstructured approach. This is in line with research conducted by Clutterbuck (2001).

\section{Method of data gathering}

The study was conducted within a qualitative research paradigm. The qualitative data collection technique in this study included a semi-structured qualitative interview with each respondent. Each interview lasted approximately 30 minutes and was structured around the two research questions. All interviews were ended with an open question allowing for the respondents to share any information or experience they felt were relevant, that had not been explored or discussed during the interview.

The following two open-ended questions were carefully formulated and put to the respondents:

- What are your expectations of the mentoring relationship?

- What are the key challenges you have to deal with in the mentoring relationship? 
Procedure

Firstly, permission was obtained from the Human Resource Manager of the company where the interviews were conducted. Thereafter the researcher contacted the mentors and mentees telephonically to establish their availability and willingness to participate in the research study. The respondents were briefed on the reason and format of the interview by means of a short introduction. They were given the opportunity to decline participation in the study. Interview appointments were accordingly arranged with each respondent.

\section{Analysis of the data}

The data was analysed utilising a qualitative content analysis process. By the end of the data collection and transcription process, a preliminary understanding of the data was achieved. Next, underlying themes were deduced, which indicated organising principles that naturally underscored the data (Creswell, 1994; Strauss \& Corbin, 1990). This was followed by a coding process, during which sections of the data were labelled as being of relevance to one or more of the identified themes. In conclusion, the themes were interpreted in the light of existing literature on the topic, allowing for meaningful interpretation of the results

\section{RESULTS}

The findings suggested that male and female mentees differ in terms of their expectations and the way they perceive challenges experienced in the formal mentoring relationship. It appeared that the male mentees were looking for career development and advancement opportunities, whilst the female mentees were more focused on the relationship as providing guidance, direction and psychosocial support (for example balancing work-family life and gaining confidence in career decision making). Establishing trust in the formal mentoring relationship appeared to be the predominant challenge to both mentors and mentees. As suggested by Strauss and Corbin (1990) and Cresswell (1994), several themes relating to the phenomenon of a mentoring relationship emerged from the data analysis. In the next section these themes will be discussed. From the themes it was possible to develop responses to the formulated research questions.

\section{Mentee expectations of the formal mentoring relationship According to the respondents' responses, the expectations of the male and female mentees differed. The male mentees formed a mentoring relationship after becoming aware of the opportunity during their induction into the organisation. As the organisation is using mentoring as a means to address employment equity, the male mentees joined the programme as a compulsory requirement in conjunction with their learnership or internship. Joining the mentoring programme was viewed by the male mentees as being purely for career development purposes with the aim of increasing their career knowledge and visibility in the firm.}

The female mentees entered into a formal mentoring relationship because it was suggested by their line management that they join the mentoring programme. Furthermore, the female mentees joined the programme for psychosocial reasons such as "balancing work-family life", "gaining confidence in making career decisions", "dealing with personality conflicts" and "learning how to build trust and confidence".

The results also suggested that the mentoring relationship was influenced by the matching of each of the mentees to a mentor. Both the mentees and the mentors identified specific criteria on which they based their selection. These criteria were generally linked to the expectations both mentors and mentees had of the formal mentoring relationship. All the mentees expressed high expectations of the mentoring programme from the outset. The female mentees indicated that their expectations were not stable but rather dynamic and constantly changing, whereas the two male mentees had clear expectations and career objectives they wanted to achieve. These expectations were established at the onset of the relationship and were reviewed on a regular basis.

Overall, mentee expectations included:

- becoming more marketable

- career development and advancement

- gaining business knowledge

- being supplied with high level information

- getting organisation tips

- receiving sound advice

- gaining a broader perspective, different viewpoints

- being offered direction and a clear vision

- receiving support in balancing work and family issues

- establishing clear career objectives and targets

- regular discussions and progress reviews

- guidance and emotional support

- self-empowerment to make own career decisions

The findings indicated that the mentees generally selected their mentors in view of their expectations. Other factors that played a role in their choice of a mentor included sharing similar values; having respect for the mentor; characteristics of the mentor such as openness, honesty, good knowledge of the industry; and having substantial experience. On the other hand, none of the white male mentors indicated that they had approached the mentees. This could be a reflection of the business structure where top management is still predominantly composed of white males. Although the mentors were approached by the organisation, all indicated that they enjoyed mentoring and were not coerced into the relationship but opted voluntarily to join. The mentors indicated that they chose their mentees on the basis of characteristics such as competence; independence; a willingness to work hard and to learn; being able to apply their minds and sharing similar values. The mentors also expected a reciprocal relationship in which the mentee had to take responsibility for his or her personal development and learning, with guidance and support from the mentor.

The mentors viewed the formal mentoring relationship as an opportunity to assist individuals to progress through a learning curve in a controlled and structured environment. They also viewed the formal mentoring relationship as an opportunity for self-reflection and sharing their own experiences with the mentees.

Perceived challenges of the formal mentoring relationship The results indicated five key themes regarding the challenges mentees and mentors were facing in terms of the mentoring relationship. These included establishing trust; cross-gender and cross-race issues; mentee dependency and mentor style; dealing with time constraints and dealing with colleague jealousy. Generally both the mentors and mentees suggested that trust was the driving factor in establishing and maintaining a reciprocal relationship. The establishment of trust appeared to be influenced by cross-gender and cross-race issues. The African male mentee found it difficult to develop trust with the white female mentor. He indicated that he did not trust his female mentor sufficiently to discuss any issues other than those necessary for the completion of his learnership programme. The coloured female mentee who was referred to her mentor (white male) by her manager had not established a relationship based on trust even after being with the mentor for just under two years. The coloured female mentee described her relationship with the mentor as being a "father-child" relationship. The three white female mentees had established careers and viewed the mentoring relationship as being between equals. Trust in the relationship was based on a form of friendship. 
Cross-race and cross-gender issues were also indicated by a remark from the African male mentee that he had previously identified a suitable white male mentor with good business knowledge but had refrained from approaching the individual as he seemed to "hide" business information, "perhaps due to negative racial feelings". One of the white female mentees also made a comment that she would not be mentored by a black male because the cultural differences would not allow her to develop the trust to discuss any issue pertaining to her career, personal and professional development.

The mentor of the coloured female found it a challenge to maintain a purely professional relationship with the mentee. He felt almost responsible to protect or shield her from the environment. Mentors also felt that the mentees did not always know how to reciprocate, and that the relationship always started as a one-sided giving approach. The challenge to ensure that the relationship became interdependent rather than dependent was often addressed through a process of guidance and challenging the mentees to reflect on their own knowledge and solutions. Some mentors found it particularly difficult to avoid assuming a leading role, especially when mentees were very junior. The preferred mentoring styles included those of coaching, guiding, counselling and allowing for the development of insight. Time was also identified as the greatest obstacle within the mentoring relationship due to mentor unavailability. Overall, the mentees found it difficult to schedule time with their mentors. Finally, the mentees generally believed that being part of the formal mentoring programme created jealousy among colleagues, as it was perceived as a means of getting ahead.

\section{DISCUSSION}

As stated, the main purpose of this study was to explore the perceptions of mentees and mentors regarding their expectations of the formal mentoring relationship and the challenges they have to deal with. In order to facilitate illumination of the social construction of the respondents, their views will also be related to existing empirical findings and relevant abstract theoretical concepts.

Mismatches between mentor and mentee expectations are quite common and often underestimated (Clutterbuck, 2002). The results of this study suggested that mentors expected the mentees to take charge of the relationship, to be self-sufficient and to use them as sounding boards, whilst the mentees expected to have a sponsor, who would tell them what to do, create career advancement opportunities for them and be a counsellor who would provide them with socioemotional support and help them build their self-confidence in career decision making. Female mentees also tended to expect a higher level of psychosocial support than their male counterparts (Jossi, 1997). Junior mentees often suffer from low self-esteem and an inability to envision a realistic future for themselves and they are therefore unlikely to take the lead in the mentoring relationship (Clutterbuck, 2002).

Although the mentors in this study were predominantly white males, research by Thomas (1999) suggests that blacks are more likely to form mentoring relationships with whites than with other blacks. First, because there are more whites in managerial ranks, blacks have little choice but to form cross-race mentoring relationships. Second, because whites have more experience in organisations, blacks are at a disadvantage unless they have a mentoring relationship with a white senior person (Ragins, 1997).

The pairing process in formal mentoring programmes is critical to the development of mentoring relationships (Scandura \& Williams, 2002). If mentors select mentees, mentoring may be more effective than if mentees alone initiate. A survey conducted by Scandura \& Williams (2002) indicated that when both parties are involved in the matching process (that is, both initiate the relationship), the most effective relationships develop. The most beneficial method of pairing may be by facilitating interaction and familiarity that allows mentors and mentees to select each other (Scandura \& Williams, 1998). Clutterbuck (2002) notes that the purpose of the relationship plays an important role in the matching process. If the goal is advancement, it may be best to pair the mentee with a white male. If the goal is building selfesteem and self-efficacy, a homogeneous pairing might be preferable. The results suggested that the expectations of the mentees and particularly the differences between male and female mentee expectations were not considered in the forming of the formal relationships.

The lack of trust suggested by the respondents could be due to factors such as the mentor-mentee selection criteria and cross-race/cross-gender issues that influenced the formal mentoring relationship. Formal mentors are often selected by mentees on the basis of their competence, status, experience and there is less likely to be mutual respect, trust, friendship, and mutual attraction than might be found in an informal mentoring relationship (Ragins \& Cotton, 1999). Race and gender composition also appeared to have posed challenges to the formal mentoring relationships. Programmes that pair mentors and mentees solely on the basis of gender or race may find that members connect on the basis of these group memberships, but they may or may not connect on other, deeper levels of diversity that define their inner values and sense of self (Athey, Avery \& Zemsky, 2000; Ragins, 2002). Furthermore, the results suggested that diversified mentoring relationships involve less of a comfort zone than homogeneous relationships. Mentoring those who are different (in terms of race and gender) may lead to discomfort, self-censorship and a lack of trust (Ragins, 2002). While many mentoring relationships involve some degree of closeness and friendship, self-censorship and discomfort with diversity may lead to emotional and relational distance in the mentoring relationship (Ragins, 2002). This in turn makes it difficult to establish trust and openness in the formal mentoring relationship.

Although the results suggested a form of paternalism in the cross-gender and cross-race relationships, it generally occurs only in a small percentage of relationships (Eby et al, 2000). Instead, it seems that the quality and actions of mentors matter more than their race or gender. As long as mentors are able to encourage mentees to feel secure within their own cultural identity and engage in activities that enhance mentees' knowledge, while remaining aware of the cultural baggage they bring to the relationship, racial similarity appears to become less consequential (Ragins, 2002; Rhodes et al, 2002).

The findings also suggested a form of marginal mentoring, that is, the scope and degree of the mentoring functions appeared to be less than those encountered in the informal mentoring relationship (Scandura \& Williams, 2002). The core purpose of the formal mentoring relationship was to advance the taskoriented and career-oriented goals for mentees. The time spent together in formal mentoring relationships was generally less than would have been in an informal mentoring relationship resulting in less psychosocial support and mentoring (Gray, 1988; Scandura \& Williams, 2002). However, time spent together is also important for the developmental relationship because it allows the mentor and mentee to tackle work-related assignments together. This in turn promotes trust, understanding and learning (Scandura \& Williams, 2002). However, Mullen (1998) reports that time spent together is not necessarily a success predictor of either the formal or the informal mentoring function. The quality rather than the quantity of time spent together are often reported to be of greater importance to both mentors and mentees (Ragins, Cotton \& Miller, 2000). 
As with all research, this study has limitations. It must be noted that, because of the qualitative nature of the study and the sampling strategy, the findings cannot be generalised to all formal mentoring relationships. Future research into mentoring and particularly into the effects of diversity in the South African work context, is required owing to the changing demographic profile of the workforce. Continuous qualitative and quantitative research with a broader representation of all gender and race groups is required to enhance the existing body of knowledge on diversified formal mentoring relationships. Ongoing research into particularly the mentoring needs of a younger generation entering an unstable and unpredictable workplace is recommended.

\section{REFERENCES}

Appelbaum, S.H., Ritchie, S. \& Shapiro, T. (1994). Mentoring revisited: an organisational behaviour construct. Journal of Management Development, 13 (4), 62-72.

Athey, S., Avery, C. \& Zemsky, P. (2000). Mentoring and diversity. American Economic Review, 90, 765-786.

Baruch, Y. (2004). Transforming careers: From linear to multidirectional career paths: Organizational and individual perspectives. Career Development International, 9 (1), 58-73.

Baugh, S.G., Lankau, M.J. \& Scandura, T.A. (1996). An investigation of the effects of protégé gender on responses to mentoring. Journal of Vocational Behavior, 49, 309-323.

Blake-Beard, S.D (2001). Taking a hard look at formal mentoring programs: a consideration of potential challenges facing women. The Journal of Management Development, 20 (4), 331-345.

Chao, G.T., Walz, P.M. \& Gardner, P.D. (1992). Formal and informal mentorships: a comparison on mentoring functions and contrast with nonmentored counterparts. Personnel Psychology, 45, 619-636.

Clawson, J.G. (1996). Mentoring in the information age. Leadership and Organisational Development Journal, 17 (3), 6-15.

Clutterbuck, D. (2001). Everyone needs a mentor: fostering talent at work. London: CIPD.

Clutterbuck, D. (2002). Building and sustaining the diversitymentoring relationship. In D. Clutterbuck \& B.R. Ragins (eds). Mentoring and diversity (pp. 87-113). Johannesburg: Butterworth-Heinemann.

Clutterbuck, D. \& Lane, G. (2005). The situational mentor. London: Gower.

Clutterbuck, D. \& Ragins, B.R. (2002). Mentoring and diversity: an international perspective. Johannesburg: ButterworthHeinemann.

Coetzee, M. \& Stone, K. (2004). Learner support: Toward learning and development. Knowres: Randburg.

Creswell, J.W. (1994). Research design: qualitative and quantitative approaches. California: Sage Publications.

Cunningham, J.B. (1993). Facilitating a mentorship program. Leadership and Organisation Development, 14, 15-20.

Denzin, N.K. \& Lincoln, Y.S. (1994). Handbook of qualitative research. Thousand Oaks, Calif: Sage.

Douglas, C.A. \& McCauley, C.D. (1999). Formal developmental relationships: a survey of organisational practices. Human Resource Development Quarterly, 10 (1), 203-220.

Dreher, G.F. \& Ash, R.A. (1990). A comparative study of mentoring among men and women in managerial, professional and technical positions. Journal of Applied Psychology, 75, 539-546.

Eby, T.L., McManus, S.E., Simon, S.A. \& Russell, J.E.A. (1998). Does every cloud have a silver lining? A study of dysfunctional mentoring experiences. Proceedings of the Southern Management Association meeting. New Orleans: La.

Eby, T.L., McManus, S.E., Simon, S.A. \& Russell, J.E.A. (2000). The protégés perspective regarding negative mentoring experiences: the development of a taxonomy. Journal of Vocational Behaviour, 57, 1-21.
Feldman, D.C. (2002). Work careers: A developmental perspective. San Francisco, CA: Jossey-Bass.

Gibb, S. (1994). Inside corporate mentoring schemes: the development of a conceptual framework. Personnel Review, 23 (3), 47-60

Gray, A.A. (1988). Developing a planned mentoring programme to facilitate career development. Career Planning and Adult Development Journal, 4, 9-16.

Hale, R. (2000). To match or mismatch? The dynamics of mentoring as a route to personal and organisational learning. Career Development International, 5 (4/5), 223234.

Hall, D.T. \& Kahn, W.A. (2002). Developmental relationships at work: A learning perspective. In C.L. Cooper \& R.J. Burke (Eds.). The new world of work: Challenges and opportunities (pp. 49-74). Oxford: Blackwell.

Hegstad, C.D. (1999). Formal mentoring as a strategy for human resource development: a review of research. Human Resource Development Quarterly, 10 (1), 383-391.

Higgins, M.C. (2000). The more, the merrier? Multiple development relationships and work satisfaction. The Journal of Management Development, 19 (4), 277-296.

Huysamen, G.K. (1994). Methodology for the social and behavioural sciences. Halfway House: Southern.

Johnson, S.K, Geroy. G.D. \& Griego, O.V. (1999). The mentoring model theory: dimensions in mentoring protocols. Career Development International, 4 (7), 384-391.

Jossi, F. (1997). Mentoring in changing times. Training, 34, 50-54.

Klasen, N. \& Clutterbuck, D. (2002). Implementing mentoring schemes: a practical guide to successful programs. London: Butterworth-Heinemann.

Kochan, K. (2002). The organisational and human dimensions of successful mentoring programs and relationships. Connecticut: Information Age.

Kogler-Hill, S. \& Bahniuk, M.H. (1998). Promoting career success through mentoring. Review of Business, 19, 4-7.

Lankau, M.J. \& Scandura, T.A. (2002). An investigation of personal learning in mentoring relationships: content, antecedents and consequences. Academy of Management Journal, 45 (4), 779-790.

Merriam, S.B. (2002). Qualitative research in practice: examples for discussion and analysis. San Francisco, CA: Jossey-Bass.

Mullen, E.J. (1998). Vocational and psychosocial mentoring functions: identifying mentors who serve both. Human Resource Development Quarterly, 9 (1), 319-331.

Murray, M. (1991). Beyond the myths and magic of mentoring: how to facilitate an effective mentoring programme. San Francisco: Jossey-Bass.

Nielson, T.R, Carlson, S.D. \& Lankau, M.J. (2001). The supportive mentor as a means of reducing work-family conflict. Journal of Vocational Behaviour, 59, 364-381.

Parsloe, E. \& Wray, M. (2000). Coaching and mentoring: practical methods to improve learning. London: Kogan Page.

Ragins, B.R. (1997). Diversified mentoring relationships in organisations: a power perspective. Academy of Management Journal, 22, 482-521.

Ragins, B.R. (2002). Understanding diversified mentoring relationships: definitions, challenges and strategies. In D. Clutterbuck \& B.R. Ragins (Eds). Mentoring and diversity: an international perspective (pp. 23-53). Oxford: ButterworthHeinemann.

Ragins, B.R. \& Cotton, J.L. (1991). Easier said than done: gender differences in perceived barriers to gaining a mentor. Academy of Management Journal, 34, 939-951.

Ragins, B.R. \& Cotton, J.L. (1999). Mentor functions and outcomes: a comparison of men and women in formal and informal mentoring relationships. Journal of Applied Psychology, 84, 529-550.

Ragins, B.R., Cotton, J. \& Miller, J. (2000). Marginal mentoring: an examination of the effects of type of mentor and program design on work and career attitudes. Academy of Management Journal, 47, 1177-1194. 
Rhodes, J.E, Reddy, R, Grossman, J.B. \& Lee, J.M. (2002). Volunteer mentoring relationships with minority youth: analysis of same-race versus cross-race matches. Journal of Applied Psychology, 32 (10), 2114-2133.

Rigsby, J.T, Siegel, P.H. \& Spiceland, J.D. (1998). Mentoring among management advisory services professionals: an adaptive mechanism to cope with rapid corporate change. Managerial Auditing Journal, 13 (2),107-116.

Scandura, T.A., Manuel, J.T, Werther, W.B. \& Lankau, M.J. (1996). Perspectives on mentoring. Leadership and Organisation Development Journal, 17 (3), 50-56.

Scandura, T.A. (1992). Mentorship and career mobility: an empirical investigation. Journal of Organizational Behavior, 13, 169-174.

Scandura, T.A. (1998). Dysfunctional mentoring relationships and outcomes. Journal of Management, 24, 449-467.

Scandura, T.A. \& Williams, E.A. (1998). Initiating mentoring: contrasting the reports of protéges in assigned and informal relationships. Proceedings of the Southern Management Association meeting. New Orleans, La.

Scandura, T.A. \& Williams, E.A. (2001). An investigation of the moderating effects of gender on the relationships between mentorship initiation and protégé perceptions of the mentoring function. Journal of Vocational Behaviour, 59, 342-363.
Scandura, T.A. \& Williams, E.A. (2002). Formal mentoring: The promise and the precipice. In C.L. Cooper \& R.J. Burke (Eds.). The new world of work: Challenges and opportunities, 49-74. Oxford: Blackwell.

Seibert, S. (1999). The effectiveness of facilitated mentoring: a longitudinal quasi-experiment. Journal of Vocational Behaviour, 54 (1), 483-502.

Strauss, A. \& Corbin, J. (1990). Basics of qualitative research: grounded theory. Procedures and techniques. Newbury Park: Sage.

Thomas, D.A. (1999). Beyond the simple demography-power hypothesis: how blacks in power influence white-mentorblack-protégé developmental relationships. In A. Murrell, F.J. Cosby \& R. Ely (Eds). Mentoring dilemmas: developmental relationships within multicultural organisations, 157-170. Lawrence Erlbaum.

Thomas, D.A. (2001). The truth about mentoring minorities: race matters. Harvard Business Review, 79 (4), 98-111.

Wickman, F. \& Sjodin, T. (1997). Mentoring. New York: McGrawHill.

Young, A.M. \& Perrewe, P.L. (2004). The role of expectations in the mentoring exchange: an analysis of mentor and protégé expectations in relation to perceived support. Journal of Managerial Issues, 16 (1), 103-127. 